\title{
Antidepressant-Drug Interactions are Potentially but Rarely Clinically Significant
}

\author{
C Lindsay DeVane*,I \\ 'Department of Psychiatry and Behavioral Sciences, Medical University of South Carolina, Charleston, SC, USA
}

\begin{abstract}
The salient pharmacologic features of the selective serotonin reuptake inhibitors (SSRIs) discovered in the late 1980s included an in vitro ability to inhibit various cytochrome P450 enzymes (CYPs). Differences in potency among the SSRIs for CYP inhibition formed the basis of a marketing focus based largely on predictions of in vivo pharmacokinetic drug interactions from in vitro data, conclusions derived from case reports, and the extrapolation of the results of pharmacokinetic studies conducted in healthy volunteers to patients. Subsequently introduced antidepressants have undergone a similar post hoc scrutiny for potential drug-drug interactions. Concern for the untoward consequences of drug interactions led the FDA to publish guidance for the pharmaceutical industry in 1997 recommending that in vitro metabolic studies be conducted early in the drug development process to evaluate inhibitory properties toward the major CYPs. However, the prevalence of clinically significant enzyme inhibition interactions occurring during antidepressant treatment remains poorly defined despite millions of exposures. Although lack of evidence does not equate to evidence of absence, sparse epidemiological and post-marketing surveillance data do not substantiate a conclusion that widespread morbidity results from antidepressant-induced drug interactions. This commentary discusses points of uncertainty and controversy in the field of drug interactions, notes areas where inadequate data exist, and suggests explanations for a low prevalence of serious interactions. The conclusion is drawn that drug interactions from CYP inhibition caused by the newer antidepressants are potentially, but rarely, clinically significant.

Neuropsychopharmacology (2006) 31, I594-1604. doi: I0.1038/sj.npp. 1301069
\end{abstract}

Keywords: drug interactions; P450; P-glycoprotein; pharmacogenetics; drug transporters

\section{Point}

When choosing a specific antidepressant for an individual patient, clinicians consider the possibility that harm may result from a drug-drug interaction. Given the statistics for drug-induced morbidity and mortality, this is a legitimate concern (Azaz-Livshits et al, 1998; Gandhi et al, 2003; Juntti-Patinen and Neuvonen, 2002). Widely quoted studies have estimated serious and fatal adverse drug reactions in hospitalized patients causing as high as 100000 deaths per year (Lazarou et al, 1998; Moore et al, 1998). There is a presumption that drug interactions significantly contribute to this mortality.

Despite more than 10-15 years of extensive worldwide clinical use of the newer antidepressants (selective serotonin reuptake inhibitors (SSRIs), bupropion, venlafaxine), an uncertainty exists about their participation in harmful drug

\footnotetext{
*Correspondence: Dr C Lindsay DeVane, Laboratory of Drug Disposition and Pharmacogenetics, Department of Psychiatry and Behavioral Sciences, Medical University of South Carolina, 173 Ashley Avenue, Charleston, SC 29425, USA. Tel: + I 843792 5448, Fax: + | 843792 6318, E-mail: devanel@musc.edu

Received 7 March 2005; revised 3 August 2005; accepted 29 September 2005

Online publication: 23 February 2006 at http://www.acnp.org/citations/ Npp022 106050160/default.pdf
}

interactions and whether their use should be avoided in patients receiving potentially interacting medications. Serious and life-threatening events, as well as fatalities, have been documented when some drug pairs have been used in therapy. This issue is not in dispute. Thiazide diuretics added to a lithium regimen, azole antifungals combined with terfenadine or cisapride, and nitrates combined with sildenafil are documented examples (Crane and Shih, 1993; Kivisto et al, 1994; Krenzelok, 2000; Monahan et al, 1990). The risk of Torsades de Pointes occurring from drug interactions mediated by cytochrome P450 enzyme (CYP) inhibition has resulted in drug withdrawals from the market (terfenadine, astemizole, cisapride) and significant labeling revisions for thioridazine, mesoridazine, and pimozide (Alfaro, 2001). The issue addressed herein is if the newer antidepressants are malicious perpetrators of CYP inhibition, why a high prevalence of significant antidepressant-drug interactions is not better documented?

\section{HISTORICAL EVIDENCE FOR ANTIDEPRESSANT- DRUG INTERACTIONS}

The availability of the SSRIs for clinical practice began with fluvoxamine in the mid-1980s in Europe and with fluoxetine 
in 1988 in the US. Despite enthusiastic acceptance for their improved tolerability and safety, efficacy appeared to be similar, but perhaps no better, compared to the tricyclic antidepressants (TCA) (Danish University Antidepressant Group, 1990; Anderson, 1998). Thus, combining SSRI and TCA was an obvious therapeutic strategy for treatment of recalcitrant depression. Previously, recognition that some antipsychotics impaired TCA elimination had been studied extensively by Gram in Norway (Gram and Overø, 1972; Gram et al, 1974; Gram, 1975) and by Nelson and Jatlow (1980) in the US. As the in vitro data emerged of the SSRI's CYP inhibitory effects, initially on CYP2D6, it was reasonable to hypothesize that they could increase the plasma concentration of TCA (Fuller and Perry, 1989; Goodnick, 1989; Vaughan, 1988). At this time, CYP2D6 was the most thoroughly studied of the genes encoding for CYPs (Gonzalez, 1992). It was of particular interest to learn if the SSRI could inhibit CYP activity, as functional polymorphisms of CYP2D6 characterized genetically deficient metabolizers (poor metabolizers, PM) as accumulating higher plasma concentrations of various substrates (Eichelbaum et al, 1982; Schmid et al, 1985). The results across studies have been generally consistent in finding potent (ie $\left.K_{\mathrm{i}}=\sim \leqslant 1.0 \mu \mathrm{M}\right) \quad$ CYP2D6 inhibition for fluoxetine $\left(K_{\mathrm{i}}=0.17-3.0 \mu \mathrm{M}\right.$; see Table 1$)$ and paroxetine $\left(K_{\mathrm{i}}=0.15-\right.$ $3.2 \mu \mathrm{M}$; Table 1). The other SSRIs have not demonstrated as meaningful CYP2D6 inhibitory effects (Table 1); neither have in vitro reports shown potent CYP2D6 inhibition by mirtazapine $\left(K_{\mathrm{i}}=41 \pm 4\right.$; Dahl et al, 1997; Störmer et al, $2000)$, venlafaxine $\left(K_{\mathrm{i}}=41.0 \pm 9.5 \mu \mathrm{M}\right.$; Ball et al, 1997), or nefazodone (Schmider et al, 1996a). The initial in vitro data for bupropion suggested that it had a low inhibitory potency versus CYP2D6 $\left(\mathrm{IC}_{50}=58 \mu \mathrm{M}\right.$; Hesse et al, 2000), but recent human volunteer studies have suggested a greater potency (GlaxoSmithKline, 2003; Kotlyar et al, 2005) underscoring the problematic interpretation of in vitro experimental data to predict accurately in vivo interactions. Sparse human data are available addressing the magnitude and significance of bupropion's CYP2D6 inhibition (Guzey et al, 2002; Pollock et al, 1996; Shad and Preskorn, 1997).

Subsequent work expanded the in vitro database to include SSRI effects on other major CYP isozymes. Most notable has been the substantial effect of fluvoxamine on CYP1A2, CYP2C19, and CYP3A4 (Brøsen et al, 1993; Daniel et al, 1994), and moderate effects of fluoxetine on CYP2C19 (Kobayashi et al, 1995). The potential contribution of norfluoxetine $\left(K_{\mathrm{i}}=1.04 \mu \mathrm{M}\right)$ to CYP3A4 inhibition following fluoxetine administration has been the subject of speculation (von Moltke et al, 1998).

In vitro data and emerging case reports of SSRI-TCA interactions (Aranow et al, 1989; Balant-Gorgia et al, 1996; Preskorn et al, 1990; Vandel et al, 1992) stimulated two types of human studies. The first investigated the clinical advantages of SSRI-TCA treatment strategies in treatmentresistant or inadequately responding depressed patients (Nelson et al, 1991; Weilburg et al, 1989). The results were mixed and have not led to recommendations for the use of combined SSRI-TCA pharmacotherapy (American Psychiatric Association, 2000). Other studies, conducted mostly in young healthy male volunteers, investigated the inhibitory effects of SSRIs and newer antidepressants on CYP2D6 and
Table I Reports of In Vitro Inhibitory Constants of Selected Antidepressants for CYP2D6

\begin{tabular}{|c|c|c|}
\hline Drug & $K_{\mathrm{i}}$ or $I C_{50}(\mu \mathrm{M})$ & Reference \\
\hline \multirow{5}{*}{$\begin{array}{l}\text { Citalopram (desmethyl } \\
\text { citalopram) }\end{array}$} & 5.1 & Crewe et al (1992 \\
\hline & $19(1.3)$ & Skjelbo and Brøsen (1992) \\
\hline & $7(6)$ & Otton et al (1993) \\
\hline & $34 ; 88(11 ; 31)$ & Belpaire et al (1998) \\
\hline & 73 & von Moltke et al (1996) \\
\hline \multirow{8}{*}{$\begin{array}{l}\text { Fluoxetine } \\
\text { (norfluoxetine) }\end{array}$} & $0.6(0.43)$ & Crewe et al (1992) \\
\hline & $0.92(0.33)$ & Skjelbo and Brøsen (1992) \\
\hline & $0.17(0.19)$ & Otton et al (1993, 1994) \\
\hline & $3.0(3.5)$ & von Moltke et al (1994) \\
\hline & 1.6 & Ball et al (1997) \\
\hline & $0.66 ; 0.93(0.95 ; 1.2)$ & Belpaire et al (1998) \\
\hline & $0.24(0.33)$ & Nielsen et al (1996) \\
\hline & $0.33(0.55)$ & Hemeryck et al (2000) \\
\hline \multirow[t]{9}{*}{ Fluvoxamine } & 8.2 & Crewe et al (1992) \\
\hline & 3.9 & Skjelbo and Brøsen (1992) \\
\hline & 1.8 & Otton et al (1993) \\
\hline & 8.0 & Ball et al (1997) \\
\hline & $12 ; 16$ & Belpaire et al (1998) \\
\hline & 4.9 & Olesen and Linnet (2000) \\
\hline & 1.3 & Nielsen et al (1996) \\
\hline & 16.6 & von Moltke et al (1995) \\
\hline & 1.45 & Fogelman et al (1999) \\
\hline \multirow[t]{9}{*}{ Paroxetine } & 0.15 & Crewe et al (1992) \\
\hline & 0.36 & Skjelbo and Brøsen (1992) \\
\hline & 0.65 & Otton et al $(1993,1994)$ \\
\hline & 1.47 & von Moltke et al (1995) \\
\hline & 3.2 & Ball et al (1997) \\
\hline & $0.44 ; 1.0$ & Belpaire et al (1998) \\
\hline & 0.17 & Fogelman et al (1999) \\
\hline & 0.86 & Nielsen et al (1996) \\
\hline & 0.54 & Hemeryck et al (2000) \\
\hline \multirow[t]{8}{*}{ Sertraline/DMS } & 0.7 & Crewe et al (1992) \\
\hline & $22.7 / 16.0$ & Skjelbo and Brøsen (1992) \\
\hline & 1.5 & Otton et al $(1993,1994)$ \\
\hline & $22.7(16.0)$ & von Moltke et al (1994) \\
\hline & 24.7 & Ball et al (1997) \\
\hline & $19 ; 20(18 ; 24)$ & Belpaire et al (1998) \\
\hline & 27 & Nielsen et al (1996) \\
\hline & $1.15 / 4.32$ & Fogelman et al (1999) \\
\hline
\end{tabular}

other CYP probe substrates (Alfaro et al, 1999, 2000; Alderman et al, 1997; Barbhaiya et al, 1995; Bergstrom et al, 1997; Brøsen et al, 1993; Greenblatt et al, 1992; Kurtz et al, 1997; Otton et al, 1993; Preskorn et al, 1994; Sproule et al, 1997; Zussman et al, 1995). The results confirmed that 
fluoxetine and paroxetine were potent in vivo inhibitors of CYP2D6, whereas the effects of sertraline were marginal, although variable, owing to the presence of an occasional outlier, especially with doses higher than $50 \mathrm{mg}$ (Zussman et al, 1995). The magnitude of SSRI CYP inhibition has been shown to be dose and concentration dependent (Alderman et al, 1997; Alfaro et al, 2000; DeVane, 1998a; Kurtz et al, 1997). The results from these human studies are consistent with competitive inhibition, although paroxetine has demonstrated mechanism-based inactivation (Bertelsen et al, 2003; Lin et al, 2001). This type of enzyme inhibition confers an additional complexity in reliably predicting in vivo interactions as the time for re-genesis of enzyme becomes an additional consideration. In contrast, competitive inhibition is transient and reversible and normal function of CYPs continues after the inhibitor has been eliminated from the body. Despite the in vitro data with paroxetine, our group found CYP2D6 inhibition by fluoxetine, sertraline, and paroxetine abated in 39 volunteers after steady-state dosing was discontinued, consistent with the elimination half-lives (Liston et al, 2002).

The in vitro and in vivo evidence suggesting fluoxetine and paroxetine can increase the plasma concentration of numerous drugs that are CYP2D6 substrates is indisputable. Product labeling cautions against combining SSRIs with CYP2D6 and/or other CYP substrate medications owing to potential metabolic drug interactions. In the mid-1990s, this scenario appeared to be a valid concern (Lane, 1996). Product labeling also implies that SSRI protein-binding displacement interactions are of concern. The evidence for this warning is likely based on the high degree of drugplasma protein binding (90\%). Authoritative reviews have repeatedly concluded that protein binding displacement interactions for drugs with pharmacokinetic characteristics of the SSRIs are of limited significance (Benet and Hoener, 2002; DeVane, 2002; Greenblatt et al, 1982; Rolan, 1994; Sansom and Evans, 1996; Sellers, 1979).

Recently, the role of drug transporters in the disposition of antidepressants has been reported (Rochat et al, 1999; Uhr et al, 2000). The discovery that paroxetine, venlafaxine, and citalopram are substrates of P-glycoprotein presents additional possibilities for SSRI-drug interactions (Uhr et al, 2003; Weiss et al, 2003).

\section{PROBLEMS AND LIMITATIONS WITH EVIDENCE FOR ANTIDEPRESSANT-DRUG INTERACTIONS}

As multiple mechanisms exist for drug interactions involving newer antidepressants, why are negative outcomes and serious adverse events, apart from the experience in occasional case reports, not more apparent when they are combined with other drugs in routine clinical care? Each of the major areas of evidence for interactions is considered below.

\section{In Vitro Studies}

In vitro models to study drug metabolism contribute substantially to our understanding of drug interactions (Bertz and Granneman, 1997; Carlile et al, 1999; Ekins et al, 2000). Given the enormous number of potentially interact- ing drug combinations, development of accurate in vitro models for in vivo predictions is a highly desirable scientific objective (Blanchard et al, 2004; Venkatakrishnan et al, 2003). The current models have several limitations beyond methodological considerations for extrapolation of results to the human situation. Multiple drugs are frequently taken by patients. The in vitro models lack sufficient ability to resolve the interactions of more than two drugs simultaneously. They cannot incorporate pharmacodynamic consequences of interactions. Generally, enzyme inhibition is more easily studied than enzyme inductive effects, yet therapeutic failure as a consequence of enzyme induction interactions is a legitimate concern (Grygiel and Birkett, 1981; Lin and Lu, 1998).

Without supporting in vivo evidence, the in vitro findings of antidepressant inhibition of a CYP enzyme are too often interpreted as indicating that the offending antidepressant will affect all substrates of the same enzyme equally (Crewe et al, 1992). Problems with in vitro models have been thoroughly discussed from the perspective of FDA guidance for drugs under development (Bjornsson et al, 2003; Yuan et al, 1999, 2002). The choice of test system can include microsomes, liver slices, hepatocyte cultures or suspension, cell lines, and recombinant $P 450$ enzymes. Most systems do not represent the physiological environment of the liver containing multiple Phase II enzymes and transporters (Pelkonen et al, 1998; Liston et al (2001)). Experimental results rank order antidepressants on the basis of their $K_{\mathrm{i}}$ or $\mathrm{IC}_{50}$ values for inhibiting a particular CYP pathway. These determinations can be influenced by analytical considerations, test conditions, the choice of probe substrates to represent the same CYP enzyme reaction (Wang et al, 2000), time-dependent inhibition, concurrent induction, the formation of active metabolites, the choice of inhibitor and probe concentrations, and the methods of data analysis (Busby et al, 1999; Chauret et al, 1998; Eagling et al, 1998; Kakkar et al, 1999; Tran et al, 2002).

The variability in the outcome of in vitro studies can be appreciated by the several-fold differences in $K_{\mathrm{i}}$ values shown in Table 1 across studies for the same antidepressant. The attempts to predict in vivo clearance changes from in vitro data have had mixed success (Bertz and Granneman, 1997; Obach, 1996, 1997, 1999; von Moltke et al, 1994, 1998). An especially important variable is the appropriate hepatic drug concentration of the inhibitor. Many drugs are subject to active uptake or efflux by drug transporters and the relevant concentration at enzymatic sites may far exceed or be lower than their unbound drug concentration in plasma (Wang, 2001). There is a current debate of whether the most appropriate estimate of inhibitor concentration should be the total plasma concentration, intrahepatic concentration, unbound concentration at the inlet to the liver, or unbound concentration in hepatic cytosol around the enzymes (Houston, 1994; Neal et al, 2003; Venkatakrishnan et al, 2003). The outcome to be avoided is underestimation, that is, false negative, prediction of an in vivo interaction.

Accurate in vitro-in vivo predictions are needed to determine if follow-up human studies should be performed to provide further guidance during drug development (Bjornsson et al, 2003). For example, nefazodone was a moderately weak inhibitor of the CYP3A4-mediated $\mathrm{N}$ dealkylation or C-hydroxylation of terfenadine in vitro 
( $K_{\mathrm{i}}=10 \pm 4$ and $41 \pm 4 \mu \mathrm{M}$, respectively), similar to sertraline $\left(K_{\mathrm{i}}=10 \pm 3\right.$ and $67 \pm 13 \mu \mathrm{M}$, respectively; Jurima-Romet et al, 1998). In vivo, nefazodone is substantially more potent as a CYP3A4 inhibitor than is sertraline (Barbhaiya et al, 1995; Green et al, 1995). As an opposing example, Crewe et al (1992) defined sertraline as a potent CYP2D6 inhibitor $\left(K_{\mathrm{i}}=0.7 \mu \mathrm{M}\right)$ but in vivo studies did not confirm meaningful CYP2D6 inhibition (Alderman et al, 1997; Preskorn et al, 1994). Fortunately, positive in vitro results are likely to be further investigated in humans.

\section{Case Reports}

Apparent drug interactions described in case reports serve a useful purpose of developing hypotheses for unexplained events. This is an inherent purpose of the MEDWATCH reporting program (FDA, 2004). Rarely is proof of causality available in case reports. Numerous criticisms that apply to population-based studies of adverse drug effects apply to case reports of drug interactions (Ray, 2003). They represent historical and anecdotal experience that includes bias in the selection of the subject in the case and, potentially, bias in the measurement of results or outcome. Validated comparisons may not be possible with other treated or unaffected patients. Isolated case reports are unreliable for representing the variability that exists in the outcome from combining drugs in patients with diverse demographic and clinical features, different degrees of drug exposure, baseline CYP activity, and tolerability to drug effects. Despite these limitations, a major purpose of the MEDWATCH and similar programs is for developing suspicion for meaningful interactions that deserve formal investigation.

\section{Pharmacokinetic Studies in Healthy Volunteers}

Several variations in the experimental design are employed in drug interaction studies. Frequently, a probe substrate for an enzyme pathway is administered in a single dose, then combined with single or multiple doses of antidepressant. Less often used is a design where the substrate is also dosed to steady-state. This is unfortunate as outcomes based on single doses may underpredict the magnitude of a drug interaction.

The choice of probe CYP substrate is critical. Ideally, the enzyme pathway of interest would be the probe's near exclusive route of elimination. An increase in area under the plasma concentration $v s$ time curve (AUC) is frequently used to reflect the magnitude of the inhibition. Desipramine and nortriptyline are common probes for CYP2D6 (Bertilsson et al, 1980; von Moltke et al, 1994). However, it is unlikely that these TCA are eliminated solely by CYP2D6 or the $5-10 \%$ of the population represented by PM devoid of CYP2D6 (see Alván et al, 1999) would quickly become toxic during chronic dosing. An additional pathway(s) must exist for elimination. Involvement of other CYPs or Phase I/II enzymes in elimination, or renal excretion of unchanged drug, will render less reliable any observed changes in pharmacokinetics for predicting impairment of other substrates. Ironically, it is this existence of parallel pathways of elimination that reduces the likelihood of serious CYP inhibitory interactions in clinical practice.
A statistically significant pharmacokinetic interaction does not necessarily lead to significant pharmacodynamic consequences. The outcome of an interaction is partly dependent upon the concentration-effect relationship of the inhibited substrate in that particular patient. Cimetidine produced a $50-60 \%$ increase in diazepam concentration, but no significant alterations in psychomotor performance (Greenblatt et al, 1984). Fluvoxamine's inhibition of theophylline (Rasmussen et al, 1995) is likely to result in significant clinical consequences owing to theophylline's steep concentration-response relationship. This contrasts with fluvoxamine's inhibition of alprazolam metabolism. Fleishaker and Hulst (1994) reported that fluvoxamine increased alprazolam concentration by $100 \%$ and extended its mean half-life from 20 to $34 \mathrm{~h}$. The effects on psychomotor performance were minimally significant ( $p<0.05$ for digit symbol substitution and a continuous performance task) with no significant changes in sedation. Thus, the effects of pharmacokinetic changes for pharmacodynamic outcomes are highly dependent on the inhibited drug and less on the inhibited pathway. Unfortunately, pharmacodynamic effects have seldom been measured in the volunteer antidepressant-drug interaction studies, partly owing to difficulties in identifying relevant effects to measure.

An example of metabolic inhibition without serious adverse events is the Pfizer studies to evaluate ziprasidone as a cause of QTc prolongation (FDA, 2000). Outcomes were recorded from administering thioridazine $300 \mathrm{mg} / \mathrm{day}$, a CYP2D6 substrate (Berecz et al, 2003), with dosing of paroxetine at $20 \mathrm{mg} /$ day. This combination caused a mean change in the QTc of $28.0 \mathrm{~ms}(+7.2 \%)$, but fortunately none of the 30 completers had a QTc $\geqslant 500 \mathrm{~ms}$, the cutoff for a potentially hazardous conduction effect. Additionally, 56 patients received SSRIs with ziprasidone and the mean change in QTc was $3.4 \mathrm{~ms}$. In another study, paroxetine (20 mg/day) and ketoconazole (400 mg/day) were administered with haloperidol. The mean QTc increase was $8.9 \mathrm{~ms}$, yet the plasma concentration of haloperidol increased by $>50 \%$. Thus, potent CYP2D6 inhibition, and in a rare experimental example, combined CYP2D6/3A4 inhibition, under circumstances of recognized hazard, led to no serious consequences. Whether a pharmacokinetic interaction is significant depends upon the magnitude of the interaction, the pharmacokinetic properties of the affected drugs, and the concentration-response relationship for the affected drug at the time of the interaction in the specific patient (Shader et al, 1996).

SSRI-drug interaction studies have mostly used healthy young males as study subjects (Alfaro et al, 2000; Alderman et al, 1997; Fleishaker and Hulst, 1994; Greenblatt et al, 1992; Kurtz et al, 1997; Liston et al, 2002; Preskorn et al, 1994; Sproule et al, 1997). This design increases homogeneity and the power to find a statistically significant effect, but it may limit the ability to generalize outcomes to women and patients of different ages. Sex is a major determinant of hepatic CYP3A4 expression although not in the small intestine where most drugs are absorbed (Paine et al, 2005; Wolbold et al, 2003). Hepatic $P 450$ content declines after 40 years to remain stable until a further decline after 70 years (Sotaniemi et al, 1997). 
The antidepressant-drug interaction studies reveal some unexplained inconsistencies. For example, Grimsley et al (1991) found that fluoxetine increased the plasma concentration of carbamazepine, a CYP3A4 substrate. The metabolism of diazepam, a partial CYP3A4 and CYP2C19 substrate (Schmider et al, 1996b), was also altered by fluoxetine, although no clinically significant alterations in psychomotor performance were found (Lemberger et al, 1988). Fluoxetine was reported to inhibit the oxidation of alprazolam in vitro (von Moltke et al, 1992), prolong its half-life, and reduce its clearance in male volunteers ( $48 \mathrm{vs}$ $61 \mathrm{ml} / \mathrm{min}$; Greenblatt et al, 1992; Lasher et al, 1991). These results suggest that fluoxetine or its active metabolite inhibit CYP3A4. However, fluoxetine had no effect on terfenadine (Bergstrom et al, 1997) or triazolam (Wright et al, 1992), other CYP3A4 substrates.

\section{Epidemiologic Data}

Many surveys of SSRI adverse events are available (AzazLivshits et al, 1998; Gandhi et al, 2003; Moore et al, 1998; Spigset, 1999). A serious adverse event, defined by the FDA, is one that results in a patient's death, is life-threatening, results in initial or prolonged hospitalization, disability, congenital anomaly, or requires intervention to prevent permanent impairment or damage (FDA, 2004). An adverse event is any undesirable experience associated with the use of a medical product in a patient. If SSRI-drug interactions were causing widespread and serious morbidity, a strong signal should appear in post-marketing surveillance reports. Deaths have been reported when SSRIs were involved in therapy (Ferslew et al, 1998; Preskorn and Baker, 1997; Sallee et al, 2000), but often under unusual circumstances, or with drug combinations that are widely documented to interact. The issue is not whether SSRI-drug interactions have resulted in serious adverse events, but the frequency of unanticipated drug interactions resulting in severe adverse events. While accurate estimates appear unavailable, several hundred million patients have taken an SSRI. In 2001, sales of the major antidepressants in the US totaled $\$ 9.3$ billion (National Institute for Health Care Management, 2002). Documentation of highly prevalent SSRI-drug interactions causing adverse events could not be found. The postmarketing surveillance of fluvoxamine can be used as an example as it was the first available SSRI and possesses the broadest CYP inhibitory profile of the antidepressants.

Fluvoxamine has pronounced inhibition of CYP1A2, CYP2C19, and CYP3A4 (Brøsen et al, 1993; Perucca et al, 1994). Significant interactions have occurred with theophylline, olanzapine and clozapine (CYP1A2 substrates), carbamazepine, amitriptyline, clomipramine and imipramine (CYP2C, CYP3A4 substrates), although not desipramine (CYP2D6 substrate). Fluvoxamine robustly elevated haloperidol concentration (a multiple CYP substrate) in three patients (Daniel et al, 1994) but extrapyramidal side effects did not increase appreciably. For drugs with a steep dose concentration-effect relationship, the consequences of fluvoxamine's inhibition are significant. For drugs with a more shallow dose-effect relationship for adverse events, other evidence, albeit indirect, is not convincing of widespread adverse interactions. Reports by fluvoxamine's manufacturer (Wagner et al, 1992, 1994) of the drug's safety database of 34587 predominantly depressed patients in 66 studies found the drug to be safe and well tolerated. The number of patients receiving other metabolized drugs was unavailable. A prescription-event monitoring of fluvoxamine was provided by Edwards et al (1994) of 10401 patients. Fluvoxamine appeared safe with no unexpected or previously undetected drug-related events. Patients took a variety of concomitant medications from 14 drug classes. Fluvoxamine potently inhibits the in vitro metabolism of caffeine (Rasmussen et al, 1998) and it reduced caffeine clearance by $80 \%$ and extended the half-life in humans from 5 to $31 \mathrm{~h}$ (Jeppesen et al, 1996a,b). The magnitude of changes suggests that caffeine intoxication should be widespread among patients taking fluvoxamine. Despite fluvoxamine's inhibition of multiple CYPs, drug interactions producing serious adverse consequences are rare events.

In the mid-1990s, we hypothesized that pharmacokinetic interactions go undetected because the consequences have subclinical outcomes (DeVane et al, 2001). Interactions could be underreported as many drug concentration measures are unavailable in clinical settings. In a prospective study of 170 patients, we documented several predictable interactions (fluvoxamine-theophylline; fluvoxamine-clozapine; Markowitz et al, 1996; DeVane et al, 1997). However, screening of patients taking fluoxetine with over 20 different drugs, and paroxetine with over 33 different drugs, did not reveal any previously undocumented pharmacokinetic interactions or adverse events. Evaluative data from blood sampling of 101 patients were available.

Several reports (Burke et al, 1996; Davies et al, 2004; Juurlink et al, 2003), including our own (Markowitz and DeVane, 1997), have noted the potential for antidepressantdrug interactions. Such predictions have been primarily based on pharmacy dispensing records. There is lack of confirmatory data to support serious antidepressant-drug interactions as widespread reality. Epidemiologic reports of SSRI adverse events (Azaz-Livshits et al, 1998; Gandhi et al, 2003; Moore et al, 1998; Spigset, 1999) do not separate out drug interactions as a cause of morbidity.

An issue often overlooked in estimating the risk for drug interactions is options for management. Bergk et al (2004) evaluated drugs concurrently prescribed to 9481 adults aged $50-75$ years. They concluded that only a small proportion of potential drug combinations offered no management options and should thus be avoided.

\section{COMPENSATORY MECHANISMS FOR MINIMIZING DRUG INTERACTIONS}

Explanations can be proposed for why highly significant antidepressant-drug interactions are rare occurrences by considering pharmacokinetic principles and patterns of clinical practice (Gibaldi and Perrier, 1982; Winkinson and Shand, 1975). Extensive continuing medical education efforts have been directed at physicians about drug interactions since the early 1990s (Nemeroff et al, 1996). Obvious interacting combinations are well publicized (SSRI-TCA), although confirmatory data that education reduces the prescribing of potentially interacting drug 
combinations appear to be lacking. Whether efforts at publicizing the potential risks of drug interactions have caused patients to be deprived of needed antidepressant treatment is equally unknown.

Clinicians dose antidepressants by titration with a low initial dose. All antidepressant product labeling recommends this practice. The result minimizes unintended CYP inhibition on pre-existing pharmacotherapy. Should an interaction occur in the opposite direction, that is, the preexisting drug therapy inhibiting the antidepressant's metabolism, dosing titration achieves the optimal antidepressant treatment at a lower daily dose than might otherwise be used if the antidepressants were given alone. This further reduces any antidepressant CYP inhibitory effects on pre-existing therapy as inhibition has been shown, by our group (DeVane, 1998a; Markowitz et al, 1996) and others (Alfaro et al, 2000; Alderman et al, 1997), to be dose dependent.

Pharmacokinetic evaluation of interactions in the human laboratory can assure $100 \%$ compliance with dosing. However, the reality is a low treatment adherence among depressed patients with prescribed pharmacotherapy. This favors minimizing an antidepressant's CYP inhibitory effects. Additionally, opposing influences may exist across patients, or within the same patient, such as induction and inhibition, to moderate the expression of a drug interaction.

Humans have developed multiple pathways of eliminating drugs, which serve to minimize the impact of impairment in any single pathway (Testa and Jenner, 1987). When a CYP inhibitory antidepressant is added to a drug regimen of susceptible substrates, two effects occur (Rowland and Matin, 1973). The degree to which metabolic blockade impairs total drug clearance will lead to increased steadystate concentration and prolongation of half-life under most circumstances. Drug clearance is an additive function of the various elimination pathways (Winkinson and Shand, 1975). Even though inhibition of a CYP metabolic pathway may be complete, the effect on steady-state plasma concentration may not be prominent, depending upon the proportion of total clearance normally contributed by the inhibited pathway. In addition to several parallel metabolic pathways existing for a drug's elimination, more than one enzyme may mediate the same pathway. For drugs eliminated by multiple pathways, as is the case for most drugs (Mitchell and Horning, 1987; Testa and Jenner, 1976), the inhibition of a single pathway will have a lesser effect on elevating concentration. This can be shown through model simulation.

The impact of parallel pathways of drug elimination was modeled by Ito et al (2005) and compared to the results of 44 drug interaction studies involving CYP2D6 substrates (Ito et al, 2004). A commonly used measure of a drug interaction is the AUC ratio of a substrate during coadministration with an inhibitor compared to the AUC of the drug administered alone. The crucial variable for predicting the extent of inhibition on the AUC ratio in vitro is the inhibitor concentration relative to the inhibition constant for that pathway, $[I] / K_{\mathrm{i}}$ (Venkatakrishnan et al, 2003). Figure 1 shows the effect of increasing inhibitor concentration on the AUC ratio for a drug with varying proportions of total elimination by CYP2D6. A second, unaffected pathway is assumed to eliminate the proportion of the drug not metabolized by CYP2D6. It can be seen that for a drug totally eliminated by CYP2D6 $(\mathrm{fm}=1)$, the AUC ratio rises dramatically when the $[I] / K_{\mathrm{i}}$ ratio exceeds a value of 1.0. However, even a small fraction of the drug eliminated by a second pathway drastically reduced the maximum effect on the AUC ratio. When $50 \%$ of the drug is removed by an alternative pathway $(\mathrm{fm}=0.5)$, then the maximum AUC ratio is 2.0, usually an insignificant drug interaction. The clinical significance of inhibition will depend upon the importance of the inhibited pathway to overall drug elimination, the activity of the various metabolites, and the concentration-response relationships for drug and metabolites in the individual patient. The variability between patients with regard to the role of primary and alternative pathways of drug elimination likely impacts the clinical importance of CYP inhibitory interactions among different patients (Guengerich, 1997; Gonzalez and Idle, 1994).

The relative importance of inhibiting a single drug elimination pathway can be considered in the context of the CYP2D6 polymorphisms that code for null enzyme activity (5-10\% of Caucasian populations; for review see Alván et al, 1999; Meyer et al, 1990). These individuals are recognizable as a PM genotype. If the CYP2D6 pathway was essential to the elimination of xenobiotics, then intuitively PM, when chronically exposed to CYP2D6 substrates, would eventually experience profound toxicity from continuous drug accumulation in the body. However, there is a lack of evidence that being a PM translates into a $5-10 \%$ frequency of toxicity in patients given drugs considered CYP2D6 substrates.

A complete inhibition of CYP2D6 by an antidepressant produces a phenocopy of a PM genotype. The frequency of PM phenocopies reported in antidepressant-drug interaction studies is summarized for CYP2D6 in Table 2. No study reported a complete conversion of all volunteers, and some studies report no conversion. Even for the most potent CYP2D6 inhibitors, paroxetine and fluoxetine, the conversion was incomplete, implying that in patients given these drugs, the metabolic impact on the CYP2D6 pathway is compromised, but not rendered unfunctional, and with less

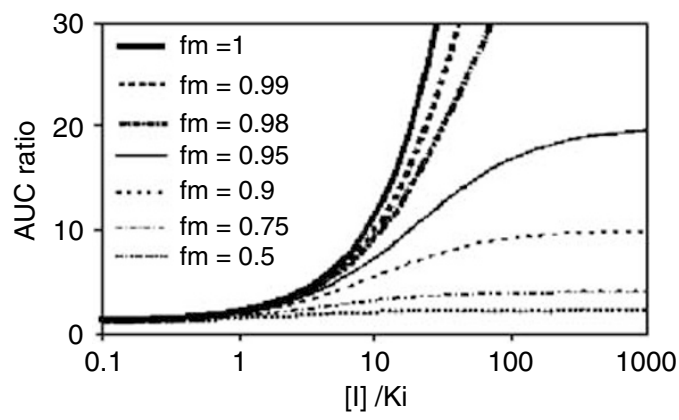

Figure I Effect of parallel pathways of drug elimination on predicted AUC ratio where a secondary pathway is unaffected by the inhibitor. Abbreviations: $\mathrm{fm}=$ fraction of substrate eliminated by the primary pathway; $[I]=$ inhibitor concentration; $K_{i}=$ inhibitory constant for the primary pathway. From lto et al (2005). Reprinted with permission from Figure 2A of Kiyomi Ito, David Hallifax, R Scott Obach, J Brian Houston (2005). Impact of parallel pathways of drug elimination and multiple cytochrome P450 involvement on drug-drug interactions: CYP2D6 paradigm. Drug Metab Dispos 33: 837-844. 
Table 2 Selected Studies Reporting CYP2D6 Phenotype Changes in Pharmacokinetic Studies

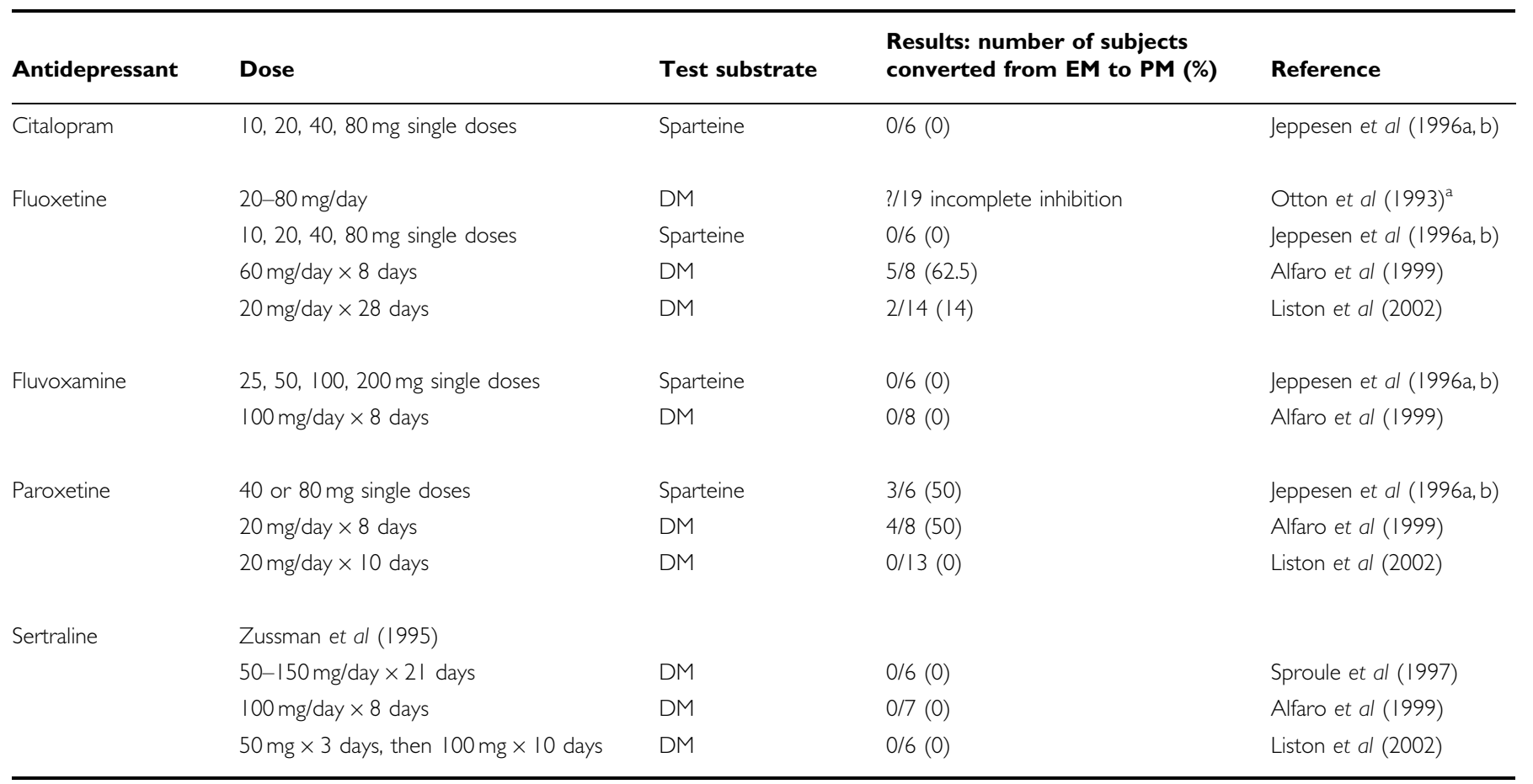

${ }^{a}$ Dextromethorphan (DM) ratio fell within the antimode between extensive metabolizer (EM) and poor metabolizer (PM) status compared with a previously characterized population, indicating incomplete inhibition.

impairment than occurs naturally in $5-10 \%$ of the general population.

\section{CONCLUSIONS}

This commentary is not meant to exonerate antidepressants as a cause of clinically important drug interactions. What is in question is their prevalence. A sensitization to drug interactions has been inculcated into the formal education of psychiatric residents for over two decades stemming from recognition that a hypertensive crisis can result from combining monoamine oxidase inhibitors (MAOI) with other drugs, principally the TCA and sympathomimetics (Harrison et al, 1990; Kahn et al, 1989). This fear may have contributed to a lower utilization of MAOI in the US compared with England (Clary et al, 1990; Henry et al, 1995). The risk of drug interactions is often taken out of context, without regard for the intended or actual benefits of drug therapy, and the morbidity and mortality associated with under treatment or non-treatment. Perhaps research and education have been successful to some degree in that physicians may be aware of, and consequently avoid, the high-risk drug combinations. Fortunately, there are physiological mechanisms to compensate for enzyme inhibition. This commentary concludes that antidepressant drug interactions are potentially, but rarely, clinically significant. With the caveat that several predictable and well-documented interactions will occur with a high frequency, mostly involving drugs with a steep dose-response relationship (eg but not inclusive: fluoxetine-phenytoin (Shader et al, 1994); fluvoxamine-clozapine, theophylline, warfarin), a reasonable conclusion is that the risks of newer antidepressants causing highly prevalent and significant drug interactions are unfounded. While clinically unimportant interactions will occur occasionally, clinically important interactions are likely to be unusual, and severe adverse interactions are rare events.

\section{REFERENCES}

Anderson IM (1998). SSRIs versus tricyclic antidepressants in depressed inpatients: a meta-analysis of efficacy and tolerability. Depress Anxiety 7(Suppl 1): 11-17.

Alderman J, Preskorn SH, Greenblatt DJ, Harrison W, Penenberg D, Allison J et al (1997). Desipramine pharmacokinetics when coadministered with paroxetine or sertraline in extensive metabolizers. J Clin Psychopharmacol 17: 284-291.

Alfaro CL (2001). Emerging role of drug interaction studies in drug development: the good, the bad, and the unknown. Psychopharm Bull 35: 80-93.

Alfaro CL, Lam F, Simpson J, Ereshefsky L (2000). CYP2D6 inhibition by fluoxetine, paroxetine, sertraline, and venlafaxine in a crossover study: intraindividual variability and plasma concentration correlations. J Clin Pharmacol 40: 58-66.

Alfaro CL, Lam YWF, Simpson J, Ereshefsky LE (1999). CYP2D6 status of extensive metabolizers after multiple-dose fluoxetine, fluvoxamine, paroxetine or sertraline. J Clin Psychopharmacol 19: $155-163$.

Alván G, Bechtel P, Iselium L, Gundert-Remy U (1999). Hydroxylation polymorphisms of debrisoquine and mephenytoin in European populations. Eur J Clin Pharmacol 39: 533-537.

American Psychiatric Association (2000). Practice guidelines for the treatment of patients with major depressive disorder (revision). Am J Psychiatry 57(4 Suppl): 1-45.

Aranow RB, Hudson JI, Pope HG, Grady TA, Laage TA, Bell IR et al (1989). Elevated antidepressant plasma levels after addition of fluoxetine. Am J Psychiatry 146: 911-913. 
Azaz-Livshits T, Levy M, Sadan B, Shalit M, Geisslinger G, Brune K (1998). Computerized surveillance of adverse drug reactions in hospital: pilot study. Br J Clin Pharmacol 45: 309-314.

Balant-Gorgia AE, Ries C, Balant LP (1996). Metabolic interaction between fluoxetine and clomipramine: a case report. Pharmacopsychiat 29: 38-41.

Ball SE, Ahern D, Scatina J, Dao J (1997). Venlafaxine: in vitro inhibition of CYP2D6 dependent imipramine and desipramine metabolism; comparative studies with selected SSRIs and effects on human hepatic CYP3A4, CYP2C9 and CYP1A2. Br J Clin Pharmacol 43: 619-626.

Barbhaiya RH, Shukla UA, Kroboth PD, Greene DS (1995). Coadministration of nefazodone and benzodiazepines: II. A pharmacokinetic interaction study with triazolam. J Clin Psychopharmacol 15: 320-326.

Belpaire FM, Wijnant P, Temmerman A, Rasmussen BB, Brøsen K (1998). The oxidative metabolism of metoprolol in human liver microsomes: inhibition by the selective serotonin reuptake inhibitors. Eur J Clin Pharmacol 54: 261-264.

Benet LZ, Hoener B (2002). Changes in plasma protein binding have little clinical relevance. Clin Pharmacol Ther 71: 115-121.

Berecz R, de la Rubia A, Dorado P, Fernandez-Salguero P, Dahl ML, Llerena A (2003). Thioridazine steady-state plasma concentrations are influenced by tobacco smoking and CYP2D6, but not by the CYP2C9 genotype. Eur J Clin Pharmacol 59: 45-50.

Bergk V, Gasse C, Rothenbacher D, Loew M, Brenner H, Haefeli WE (2004). Drug interactions in primary care: impact of a new algorithm on risk determination. Clin Pharmacol Ther 76: 85-96.

Bergstrom RF, Goldberg MJ, Cerimele BJ, Hatcher BL (1997). Assessment of the potential for a pharmacokinetic interaction between fluoxetine and terfenadine. Clini Pharmacol Ther 62: 643-651.

Bertelsen KM, Venkatakrishnan K, von Moltke LL, Obach RS, Greenblatt DJ (2003). Apparent mechanism-based inhibition of human CYP2D6 in vitro by paroxetine: comparison with fluoxetine and quinidine. Drug Metab Dispos 31: 289-293.

Bertilsson L, Eichelbaum M, Mellstrom B, Sawe J, Scholtz H-U, Sjoqvist F (1980). Nortritpyline and antipyrine clearance in relation to debrisoquine hydroxylation in man. Life Sci 27: 1673-1677.

Bertz RJ, Granneman GR (1997). Use of in vitro and in vivo data to estimate the likelihood of metabolic pharmacokinetic interactions. Clin Pharmacokinet 32: 210-258.

Bjornsson TD, Callaghan JT, Einolf HJ, Fischer V, Gan L, Grimm S et al (2003). The conduct of in vitro and in vivo drug-drug interaction studies: a pharmaceutical research and manufacturers of America (PhRMA) perspective. Drug Metab Dispos 31: 815-832.

Blanchard N, Richert L, Coassolo P, Lave T (2004). Qualitative and quantitative assessment of drug-drug interaction potential in man, based on Ki, IC50 and inhibitor concentration. Curr Drug Metab 5: 147-156.

Brøsen K, Skjelbo E, Rasmussen BB, Poulsen HE, Loft S (1993). Fluvoxamine is a potent inhibitor of cytochrome P4501A2. Biochem Pharmacol 45: 1211-1214.

Burke MJ, Carmichael CA, Harvey A, Preskorn SH (1996). The prevalence of polypharmacy as a potential risk for drug interactions in the outpatient treatment of major depression and the inpatient treatment of schizophrenia. Poster presented at the 36th Annual NCDEU Meeting, Boca Raton, Florida, May $28-31$.

Busby Jr WF, Ackermann JM, Crespi CL (1999). Effect of methanol, ethanol, dimethyl sulfoxide, and acetonitrile on in vitro activities of cDNA-expressed human cytochromes P-450. Drug Metab Dispos 27: 246-249.

Carlile DJ, Hakooz N, Bayliss KM, Houston JB (1999). Microsomal prediction of in vivo clearance of CYP2C9 substrates in humans. Br J Clin Pharmacol 47: 625-635.
Chauret N, Gauthier A, Nicoll-Briffith DA (1998). Effect of common organic solvents on in vitro cytochrome P450-mediated meteabolic activities in human liver microsomes. Drug Metab Dispos 26: 1-4.

Clary C, Mandos LA, Schweizer E (1990). Results of a brief survey on the prescribing practices for monoamine oxidase inhibitor antidepressants. J Clin Psychiatry 51: 226-231.

Crane JK, Shih HT (1993). Syncope and cardiac arrhythmia due to an interaction between itraconazole and terfenadine. Am J Med 95: 445-446.

Crewe HK, Lennard MS, Tucker GT, Woods FR, Haddock RE (1992). The effect of selective serotonin re-uptake inhibitors on cytochrome P4502D6 activity in human liver microsomes. $\mathrm{Br} \mathrm{J}$ Clin Pharmacol 34: 262-265.

Dahl M-L, Voortman G, Alm C, Elwin CE, Delbressine L, Vos R et al (1997). In vitro and in vivo studies on the disposition of mirtazapine in humans. Clin Drug Ivest 13: 37-46.

Daniel DG, Randolph C, Jaskiw G, Handel S, Williams T, AbiDargham A et al (1994). Coadministration of fluvoxamine increases serum concentrations of haloperidol. J Clin Psychopharmacol 14: 340-343.

Danish University Antidepressant Group (1990). Paroxetine: a selective serotonin reuptake inhibitor showing better tolerance, but weaker antidepressant effect than clomipramine in a controlled multi-center study. J Affect Disord 18: 289-299.

Davies SJC, Eayrs S, Pratt P, Lennard MS (2004). Potential for drug interactions involving cytochromes P450 2D6 and $3 \mathrm{~A} 4$ on general adult psychiatric and functional elderly psychiatric wards. Br J Clin Pharmacol 57: 464-472.

DeVane CL (1998a). Clinical implications of dose-dependent cytochrome $P-450$ drug interactions with antidepressants. Hum Psychopharmacol 13: 329-336.

DeVane CL (2002). Clinical significance of drug plasma protein binding and binding displacement drug interactions. Psychopharmacol Bull 36: 5-21.

DeVane CL, Markowitz JS, Hardesty SJ, Mundy S, Gill HS (1997). Fluvoxamine-induced theophylline toxicity. Letter. Am J Psychiarty 154: 1317-1318.

DeVane CL, Markowitz JS, Liston HL, Risch SC (2001). Charleston antidepressant drug interactions surveillance program (CADISP). Psychopharmacol Bull 35: 50-61.

Eagling VA, Tjia JF, Back DJ (1998). Differential selectivity of cytochrome $P 450$ inhibitors against probe substrates in human and rat liver microsomes. Br J Clin Pharmacol 45: 107-114.

Edwards JG, Inman WHW, Wilton L, Pearce GL (1994). Prescription-event monitoring of 10,401 patients treated with fluvoxamine. Br J Psychiatry 164: 387-395.

Eichelbaum M, Bertilsson L, Sawe J, Zekorn C (1982). Polymorphic oxidation of sparteine and debrisoquine: related pharmacogenetic entities. Clin Pharmacol Ther 31: 184-186.

Ekins S, Ring BJ, Grace J, McRobie-Belle DJ, Wrighton SA (2000). Present and future in vitro approaches for drug metabolism. J Pharmacol Toxicol Methods 44: 313-324.

Ferslew KE, Hagardorn AN, Harlan GC, McCormick WJ (1998). A fatal drug interaction between clozapine and fluoxetine. J Forensic Sci 43: 1082-1085.

Fleishaker JC, Hulst LK (1994). A pharmacokinetic and pharmacodynamic evaluation of the combined administration of alprazolam and fluvoxamine. Eur J Clin Pharmacol 46: 35-39.

Fogelman SM, Schmider J, Venkatakrishnan K, von Moltke LL, Harmatz JS, Shader RI et al (1999). O- and N-demethylation of venlafaxine in vitro by human liver microsomes and by microsomes from cDNA-transfected cells: effect of metabolic inhibitors and SSRI antidepressants. Neuropsychopharmacology 20: $480-490$.

Food and Drug Administration (2000). Briefing Document for Zeldox Capsules. 19 July 2000. FDA Psychopharmacological Drugs Advisory Committee. 
Food and Drug Administration. MedWatch (2004). The FDA Safety Information and Adverse Event Reporting Program 2004. (Internet: www.fda.gov/medwatch).

Fuller RW, Perry KW (1989). Effect of fluoxetine pretreatment on plasma and tissue concentrations of desipramine in rats. Res Commun Chem Pathol Pharmacol 66: 375-384.

Gandhi TJ, Weingart SN, Borus J, Seger AC, Peterson J, Burdick E et al (2003). Adverse drug events in ambulatory care. $N$ Engl J Med 358: 1556-1564.

Gibaldi M, Perrier D (1982). Pharmacokinetics, 2nd revised and expanded. Marcel Dekker Inc.: New York.

GlaxoSmithKline (2003). Research Triangle Park, NC, Wellbutrin (bupropion $\mathrm{HCl}$ ) [package insert].

Gonzalez FJ (1992). Human cytochromes P450: problems and prospects. Trends Pharmacol Sci 13: 346-352.

Gonzalez FJ, Idle JR (1994). Pharmacogenetic phenotyping and genotyping. Present status and future potential. Clin Pharmacokinet 26: 59-70.

Goodnick PJ (1989). Influence of fluoxetine on plasma levels of desipramine. Am J Psychiatry 146: 552.

Gram LF (1975). Effects of perphenazine on imipramine metabolism in man. Psychopharmacol Commun 1: 165-175.

Gram LE, Over $\varnothing$ KF (1972). Drug interaction: inhibitory effect of neuroleptics on metabolism of tricyclic antidepressants in man. BMJ 1: 463-465.

Gram LE, Over $\varnothing$ KF, Kirk L (1974). Influence of neuroleptics and benzodiazepines on metabolism of tricyclic antidepressants in man. Am J Psychiatry 131: 863-866.

Green DS, Salazar DE, Dockens RC, Kroboth P, Barbhaiya RH (1995). Coadministration of nefazodone with benzodiazepines, III: a pharmacokinetic interaction study with alprazolam. J Clin Psychopharmacol 15: 399-408.

Greenblatt DJ, Abernathy DR, Morse DS, Harmatz JS, Shodes RI (1984). Clinical importance of the interaction of diazepam and cimetidine. N Engl J Med 318: 1639-1643.

Greenblatt DJ, Preskorn SH, Cotreau MM, Horst WD, Harmatz JS (1992). Fluoxetine impairs clearance of alprazolam but not of clonazepam. Clin Pharmacol Ther 52: 479-486.

Greenblatt DJ, Sellers EM, Koch-Weser J (1982). Importance of protein binding for the interpretation of serum or plasma drug concentrations. J Clin Pharmacol 22: 259-263.

Grimsley SR, Jann MW, Carter JG, D'Mello AP, D'Souza MJ (1991). Increased carbamazepine plasma concentrations after fluoxetine coadministration. Clin Pharmacol Ther 50: 10-15.

Grygiel JJ, Birkett DJ (1981). Cigarette smoking and theophylline clearance and metabolism. Clin Pharmacol Ther 30: 491-496.

Guengerich FP (1997). Role of cytochrome P450 enzymes in drugdrug interactions. Adv Pharmacol 43: 7-35.

Guzey C, Norstrom A, Spigset O (2002). Change from the CYP2D6 extensive metabolizer to the poor metabolizer phenotype during treatment with bupropion. Ther Drug Monit 24: 436-437.

Harrison WM, McGrath PJ, Stewart JW, Quitkin F (1990). MAOIs and hypertensive crises: the role of OTC drugs. J Clin Psyuchiatry 51: 212-213.

Hemeryck A, DeVriendt C, Belpaire FM (2000). Effect of selective serotonin reuptake inhibitors on the oxidative metabolism of propafenone: in vitro studies using human liver microsomes. J Clin Psychopharmacol 20: 428-434.

Henry JA, Alexander CA, Sener EK (1995). Relative mortality from overdose of antidepressants. BMJ 310: 221-224.

Hesse LM, Venkatakrishnan K, Court MH et al (2000). CYP2B6 mediates the in vitro hydroxylation of bupropion: potential drug interactions with other antidepressants. Drug Metab Dispos 28: $1176-1183$.

Houston JB (1994). Utility of in vitro drug metabolism data in predicting in vivo metabolic clearance. Biochem Pharmacol 47: 1469-1479.
Ito K, Brown HS, Houston JB (2004). Database analyses for the prediction of in vivo drug-drug interactions from in vitro data. Br J Clin Pharmacol 57: 473-486.

Ito K, Hallifax D, Obach RS, Houston JB (2005). Impact of parallel pathways of drug elimination and multiple cytochrome $P 450$ involvement on drug-drug interactions: CYP2D6 paradigm. Drug Metab Dispos 33: 837-844.

Jeppesen U, Gram LF, Vistisen K, Loft S, Poulsen HE, Brøsen K (1996a). Dose-dependent inhibition of CYP1A2, CYP2C19 and CYP2D6 by citalopram, fluoxetine, fluvoxamine and paroxetine. Eur J Clin Pharmacol 51: 73-78.

Jeppesen U, Loft S, Poulsen HE, Brsen K (1996b). A fluvoxaminecaffeine interaction study. Pharmacogenetics 6: 213-222.

Juntti-Patinen L, Neuvonen PJ (2002). Drug-related deaths in a university central hospital. Eur J Clin Pharmacol 58: 479-482.

Jurima-Romet M, Wright M, Neigh S (1998). Terfenadineantidepressant interactions: an in vitro inhibition study using human liver microsomes. Br J Clin Pharmacol 45: 318-321.

Juurlink DN, Mamdani M, Kopp A, Laupacis A, Redelmeier DA (2003). Drug-drug interactions among elderly patients hospitalized for drug toxicity. JAMA 289: 1652-1658.

Kahn D, Silver JM, Opler LA (1989). The safety of switching rapidly from tricyclic antidepressants to monoamine oxidase inhibitors. J Clin Psychopharmacol 9: 198-202.

Kakkar T, Boxenbaum H, Mayersohn M (1999). Estimation of $\mathrm{Ki}$ in a competitive enzyme-inhibition model: comparisons among three methods of data analysis. Drug Metab Dispos 27: 756-762.

Kivisto KT, Neuvonen PJ, Klotz U (1994). Inhibition of terfenadine metabolism pharmacokinnetics and pharmacodynamic consequences. Clin Pharmacokinet 27: 1-5.

Kobayashi K, Yamamoto T, Chiba K, Tani M, Ishizaki T, Kuroiwa $\mathrm{Y}$ et al (1995). The effects of selective serotonin reuptake inhibitors and their metabolites on s-mephenytoin 4-hydroxylase activity in human liver microsomes. $\mathrm{Br}$ J Clin Pharmacol 40: 481-485.

Kotlyar M, Brauer LH, Tracy TS, Hatsukami DK, Harris J, Bronars CA et al (2005). Inhibition of CYP2D6 activity by bupropion. J Clin Psychopharmacol 25: 226-229.

Krenzelok EP (2000). Sildenafil: clinical toxicology profile. J Toxicol Clin Toxicol 38: 645-651.

Kurtz DL, Bergstrom RF, Goldberg MJ, Cerimele BJ (1997). The effect of sertraline on the pharmacokinetics of desipramine and imipramine. Clin Pharmacol Ther 62: 145-156.

Lane RM (1996). Pharmacokinetic drug interaction potential of selective serotonin reuptake inhibitors. Int Clin Psychopharmacol 11(Suppl 5): 31-61.

Lasher TA, Fleishaker JC, Steenwyk RC, Antal EJ (1991). Pharmacokinetic pharmacodynamic evaluation of the combined administration of alprazolam and fluoxetine. Psychopharmacology 104: 323-327.

Lazarou U, Pomeranz BH, Corey PN (1998). Incidence of adverse drug reactions in hospitalized patients: a meta-analysis of prospective studies. JAMA 270: 1200-1205.

Lemberger L, Rowe H, Bosomworth JC, Tenbarge JB, Bergstrom RF (1988). The effect of fluoxetine on the pharmacokinetics and psychomotor responses of diazepam. Clin Pharmacol Ther 43: 412-419.

Lin JH, Lu AY (1998). Inhibition and induction of cytochrome P450 and the clinical implications. Clin Pharmacokinet 35: 361-390.

Lin Y, Lu P, Tang C, Mei Q, Sandig G, Rodrigues AD et al (2001). Substrate inhibition kinetics for cytochrome P450-catalyzed reactions. Drug Metab Dispos 29: 368-374.

Liston HL, DeVane CL, Boulton DW, Risch SC, Markowitz JS, Goldman J (2002). Differential time course of cytochrome P450 2D6 enzyme inhibition by fluoxetine, sertraline, and paroxetine in healthy volunteers. J Clin Psychopharmacol 22: 169-173. 
Liston HL, Markowitz JS, DeVane CL (2001). Drug glucuronidation in clinical psychopharmacology. J Clin Psychopharmacol 21: 500-515.

Markowitz J, DeVane CL (1997). The drug interaction potential of fluoxetine, sertraline, and paroxetine in four state psychiatric hospitals. Ther Drug Monit 19: 244-245.

Markowitz JS, Gill HS, Lavia M, Brewerton TD, DeVane CL (1996). Fluvoxamine-clozapine dose dependent interaction. Can $J$ Psychiatry 41: 670-671.

Meyer UA, Zanger UM, Grant D et al (1990). Genetic polymorphisms of drug metabolism. Adv Drug Res 19: 197-241.

Mitchell JR, Horning MG (eds) (1987). Drug Metabolism and Drug Toxicity. Raven Press: New York.

Monahan BP, Ferguson CL, Killeavy ES, Lloyd BK, Troy J, Cantilena Jr LR (1990). Torsades de pointes occurring in association with terfenadine use. JAMA 264: 2788-2790.

Moore N, Lecointre D, Noblet C, Mabille M (1998). Frequency and cost of serious adverse drug reactions in a department of general medicine. Br J Clin Pharmacol 45: 301-308.

National Institute for Health Care Management (2002). Internet www.nihcm.org/spending2001.pdf Prescription Drug Expenditures in 2001, May 6, 2002, pp 1-19.

Neal JM, Kunze KL, Levy RH, O’Reilly RA, Trager WF (2003). KiIV, an in vivo parameter for predicting the magnitude of a drug interaction arising from competitive enzyme inhibition. Drug Metab Dispos 31: 1043-1048.

Nielsen KK, Flinois JP, Beaune P, Brosen K (1996). The biotransformation of clomipramine in vitro, identification of the cytochrome P450s responsible for the separate metabolic pathways. J Pharmacol Exp Ther 277: 1659-1664.

Nelson JC, Jatlow PI (1980). Neuroleptic effect on desipramine steady-state plasma concentrations. Am J Psychiatry 137: $1232-1234$.

Nelson JC, Mazure CM, Bowers MB, Jatlow PI (1991). A preliminary, open study of the combination of fluoxetine and desipramine for rapid treatment of major depression. Arch Gen Psychiatry 48: 303-307.

Nemeroff CB, DeVane CL, Pollock BG (1996). Antidepressants and the cytochrome $P 450$ system. Am J Psychiatry 153: 311-320.

Obach RS (1996). The importance of nonspecific binding in in vitro matrices, its impact on enzyme kinetic studies of drug metabolism reactions, and implications for in vitro-in vivo correlations. Drug Metab Dispos 24: 1047-1049.

Obach RS (1997). Nonspecific binding to microsomes: impact on scale-up of in vitro intrinsic clearance to hepatic clearance as assessed through examination of warfarin, imipramine, and propranolol. Drug Metab Dispos 25: 1359-1369.

Obach RS (1999). Prediction of human clearance of twentynine drugs from hepatic microsomal intrinsic clearance data: an examination of in vitro half-life approach and nonspecific binding to microsomes. Drug Metab Dispos 27: 1350-1359.

Olesen OV, Linnet K (2000). Fluvoxamine-clozapine drug interaction: inhibition in vitro of five cytochrome $P 450$ isoforms involved in clozapine metabolism. J Clin Psychopharmacol 20: $35-42$.

Otton SV, Ball SE, Cheung SW, Inaba T, Sellers EM (1994). Comparative inhibition of the polymorphic enzyme CYP2D6 by venlafaxine and other 5HT uptake inhibitors. Clin Pharmacol Ther 55: 141.

Otton SV, Wu D, Joffe RT, Cheung SW, Sellers EM (1993). Inhibition by fluoxetine of cytochrome P450 2D6 activity. Clin Pharmacol Ther 53: 401-409.

Paine MF, Ludington SS, Chen M-L, Stewart PW, Shiew-Mei H, Watkins PB (2005). Do men and women differ in proximal small intestinal CYP3A or P-glycoprotein expression? Drug Metab Dispos 33: 426-433.
Pelkonen O, Maenpaa J, Taavitsainen P, Rautio A, Raunio H (1998). Inhibition and induction of cytochrome P450 enzymes. Xenobiotica 28: 1203-1253.

Perucca E, Gatti G, Cipolla G, Spina E, Barel S, Soback S et al (1994). Inhibition of diazepam metabolism by fluvoxamine: a pharmacokinetic study in norml volunteers. Clin Pharmacol Ther 56: 471-476.

Pollock BG, Sweet RA, Kirshner M, Reynolds III CF (1996). Bupropion plasma levels and CYP2D6 phenotype. Ther Drug Monit 18: 581-585.

Preskorn SH, Alderman J, Chung M, Harrison W, Messig M, Harris $S$ et al (1994). Pharmacokinetics of desipramine coadministered with sertraline or fluoxetine. J Clin Psychopharmacol 14: 90-98.

Preskorn SH, Baker B (1997). Fatality associated with combined fluoxetine-amitriptyline therapy. JAMA 277: 1682.

Preskorn SH, Beber JH, Faul JC, Hirshfeld RMA (1990). Serious adverse effects of combining fluoxetine and tricyclic antidepressants. Am J Psychiatry 147: 532.

Rasmussen BB, Maenpaa J, Pelkonen O, Loft S, Poulsen HE, Lykkesfeldt J et al (1995). Selective serotonin reuptake inhibitors and theophylline metabolism in human liver microsomes: potent inhibition by fluvoxamine. Br J Clin Pharmacol 39: 151-159.

Rasmussen BB, Neilsen TL, Brosen K (1998). Fluvoxamine is a potent inhibitor of the metabolism of caffeine in vitro. Pharmacol Toxicol 83: 240-245.

Ray WA (2003). Population-based studies of adverse drug effects. $N$ Engl J Med 349: 1592-1594.

Rochat B, Baumann P, Andus KL (1999). Transport mechanisms for the antidepressant citalopram in brain microvessel endothelium. Brain Res 831: 229-236.

Rolan PE (1994). Plasma protein binding displacement interactions - why are they still regarded as clinically important? Br J Clin Pharmacol 37: 125-128.

Rowland M, Matin SB (1973). Kinetics of drug-drug interactions. J Pharmacokinet Biopharm 1: 553-567.

Sallee FR, DeVane CL, Ferrell RE (2000). Fluoxetine related death in a child with cytochrome P450 2D6 deficiency. J Child Adolesc Psychopharmacol 10: 27-34.

Sansom LN, Evans AM (1996). What is the true clinical significance of plasma protein binding displacement interactions? Drug Safety 12: 223-227.

Schmid B, Bircher J, Preisig R, Kupfer A (1985). Polymorphic dextromethorphan metabolism: co-segregation of oxidative $\mathrm{O}-$ demethylation with debrisoquine hydroxylation. Clin Pharmacol Ther 38: 618-624.

Schmider J, Greenblatt DJ, von Moltk LL, Harmatz JS, Shader RI (1996a). Inhibition of cytochrome $P 450$ by nefazodone in vitro: studies of dextromethorphan $\mathrm{O}$ - and $\mathrm{N}$-demethylation. $\mathrm{Br} \mathrm{J} \mathrm{Clin}$ Pharmacol 41: 339-343.

Schmider J, Greenblatt DJ, von Moltke LL, Shader RI (1996b). Relationship of in vitro data on drug metabolism to in vivo pharmacokinetics and drug interactions: implications for diazepam disposition in humans. J Clin Psychopharmacol 16: 267-272.

Sellers EM (1979). Plasma protein displacement interactions are rarely of clinical significance. Pharmacology 18: 225-227.

Shad MU, Preskorn SH (1997). A possible bupropion and imipramine interaction. J Clin Psychopharmacol 17: 118-119.

Shader RI, Greenblatt DJ, von Moltke LL (1994). Fluoxetine inhibition of phenytoin metabolism. J Clin Psychopharmacol 14: 375-376.

Shader RI, von Moltke LL, Schmider J, Harmatz JS, Greenblatt DJ (1996). The clinician and drug interactions - an update. J Clin Psychopharmacol 16: 197-201.

Skjelbo E, Brøsen K (1992). Inhibitors of imipramine metabolism by human liver microsomes. Br J Clin Pharmacol 34: 256-261.

Sotaniemi EA, Arranto AJ, Pelkonen O, Pasanen M (1997). Age and cytochrome P450-linded drug metabolin humans: an analysis of 
226 subjects with equal histopathologic conditions. Clin Tharmacol Ther 61: 331-339.

Spigset O (1999). Adverse reactions of selective serotonin reuptake inhibitors: reports from a spontaneous reporting system. Drug Safety 20: 277-287.

Sproule BA, Otton SV, Cheung SW, Zhong XH, Romach MK, Sellers EM (1997). CYP2D6 inhibition in patients treated with sertraline. J Clin Psychopharmacol 17: 102-106.

Störmer E, Von Moltke LL, Shader RI, Greenblatt DJ (2000). Metabolism of the antidepressant mirtazapine in vitro: contribution of cytochromes P-450 1A2, 2D6, and 3A4. Drug Metab Dispos 28: 1168-1175.

Testa B, Jenner P (1976). Drug Metabolism Chemical and Biochemical Aspects. Marcel Kekker Inc.: New York.

Tran TH, von Moltke LL, Venkatakrishnan K, Granda BW, Gibbs MA, Obach RS et al (2002). Microsomal protein concentration modifies the apparent inhibitory of CYP3A inhibitors. Drug Metab Dispos 30: 1441-1445.

Uhr M, Grauer MT, Holsboer F (2003). Differential enhancement of antidepressant penetration into the brain in mice with abvblab (mrdlab) P-glycoprotein gene disruption. Biol Psychiatry 15: 840-846.

Uhr M, Steckler T, Yassouridis A, Holsboer F (2000). Penetration of amitriptyline, but not of fluoxetine, into brain is enhanced in mice with blood-brain barrier deficiency due to mdrla Pglycoprotein gene disruption. Neuropsychopharmacology 22: 380-387.

Vandel S, Bertschy G, Bonin G, Neselof S, Francois TH, Vandel B et al (1992). Tricyclic antidepressant plasma levels after fluoxetine addition. Neuropsychobiology 25: 202-207.

Vaughan DA (1988). Interaction of fluoxetine with tricyclic antidepressants. Am J Psychiatry 145: 1478.

Venkatakrishnan K, non Moltke LL, Obach RS, Greenblatt DJ (2003). Drug metabolism and drug interactions: application and clinical value of in vitro models. Curr Drug Metab 4: 423-459.

von Moltke L, Greenblatt DJ, Shader RI (1992). In vitro inhibition of alprazolam oxidation by fluoxetine and norfluoxetine. J Clin Pharmacol 32: 764 (Abstract).

von Moltke LL, Greenblatt DJ, Cotreau-Bibbo MM, Duan SX, Harmatz JS, Shader RI (1994). Inhibition of desipramine hydroxylation in vitro by serotonin-reuptake inhibitor antidepressants, and by quinidine and ketoconazole: a model system to predict drug interactions in vivo. J Pharm Exp Ther 268: $1278-1283$.

von Moltke LL, Greenblatt DJ, Court MH, Duzn SX, Harmatz JS, Shader RI (1995). Inhibition of alprazolam and desipramine hydroxylation in vitro by paroxetine and fluvoxamine: comparison with other selective serotonin reuptake inhibitor antidepressants. J Clin Psychopharmacol 15: 125-131. von Moltke LL, Greenblat DJ, Duan SX, Schmider J, Kudchadker L, Fogelman SM et al (1996). Phenacetin O-deethylation by human liver microsomes in vitro: inhibition by chemical probes, SSRI antidepressants, nefazodone and venlafaxine. Psychopharmacology 128: 398-407.

von Moltke LL, Greenblatt DJ, Schmider J, Wright CE, Harmatz JS, Shader RI et al (1998). In vitro approaches to predicting drug interactions in vivo. Biochem Pharmacol 55: 113-122.

Wagner W, Plekkenpol B, Gray TE, Vlaskamp H, Essers H (1992). Review of fluvoxamine safety database. Drugs 43(Suppl 2): $48-54$.

Wagner W, Zaborny BA, Gray TE (1994). Fluvoxamine. A review of its safety profile in world-wide studies. Int Clin Psychopharmacol 9: 223-227.

Wang J-S (2001). In vivo and in vitro studies on drug metabolism and interactions involving mibefradil, isradipine, lidocaine, selegiline and metronidazole. University of Helsinki Academic Dissertation, pp 1-65.

Wang RW, Newton DJ, Liu N, Atkins WM, Lu AY (2000). Human cytochrome P-450 3A4: in vitro drug-drug interaction patterns are substrate-dependent. Drug Metab Dispos 28: 360-366.

Weilburg JB, Rosenbaum JF, Biederman J, Sachs GS, Pollack MH, Kelly K (1989). Fluoxetine added to non-MAOI antidepressants converts nonresponders to responders: a preliminary report. J Clin Psychiatry 50: 447-449.

Weiss J, Dormann S-MG, Martin-Facklam M, Kerpen CJ, KetabiKiyanvash N, Haefeli WE (2003). Inhibition of P-glycoprotein by newer antidepressants. J Pharm Exp Ther 305: 197-204.

Winkinson GR, Shand DG (1975). A physiological approach to hepatic drug clearance. Clin Pharmacol Ther 18: 377-390.

Wolbold R, Klein K, Burk O et al (2003). Sex is a major determinant of CYP3A4 expression in human liver. Hepatology 38: 978-988.

Wright CE, Lasher-Sisson TA, Steenwyk RC, Swanson CN (1992). A pharmacokinetic evaluation of the combined administration of triazolam and fluoxetine. Pharmacotherapy 12: 103-106.

Yuan R, Parmelee T, Balian JD, Uppoor RS et al (1999). In vitro metabolic interaction studies: experience of the Food and Drug Administration. Clin Pharmacol Ther 66: 9-15.

Yuan R, Madani S, Xiao-Xiong W, Reynolds K, Huang S-M (2002). Evaluation of cytochrome $P 450$ probe substrates commonly used by the pharmaceutical industry to study in vitro drug interactions. Drug Metab Dispos 30: 1311-1319.

Zussman BD, Davie CC, Fowles SE, Duman R, Lang U, Wargenau $M$ et al (1995). Sertraline, like other SSRIs, is a significant inhibitor of desipramine metabolism in vivo. $\mathrm{Br} \mathrm{J}$ Clin Pharmacol 39: 550-551. 